\title{
Actinocamax cf. manitobensis from the Kangerdlugssuaq area, southern East Greenland
}

\author{
WALTER KEGEL CHRISTENSEN AND ELLA HOCH
}

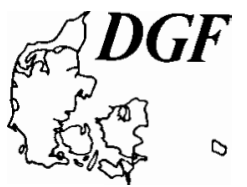

\begin{abstract}
Christensen, W. K. and Hoch, E.: Actinocamax cf. manitobensis from the Kangerdlugssuaq area, southern East Greenland. Bull. geol. Soc. Denmark, vol. 32, pp. 33-42, Copenhagen, November, 15th, 1983. https://doi.org/10.37570/bgsd-1983-32-02
\end{abstract}

\begin{abstract}
A recent find of Actinocamax cf. manitobensis from the Kangerdlugssuaq area in southern East Greenland is described, and the belemnites from the same area described earlier are discussed and revised. The belemnites from East Greenland are closely comparable to the belemnites from West Greenland and North America. They are most likely from the Middle Turonian, but the maximum stratigraphic range may be from uppermost Lower-Upper Turonian. Biostratigraphic age determinations of the lithostrati-graphic units proposed earlier for the area are slightly revised.
\end{abstract}

Walter Kegel Christensen and Ella Hoch, Geological Museum, Øster Voldgade 5-7, DK-1350 Copenhagen, Denmark. February 15th, 1983.

\section{Introduction}

Upper Cretaceous belemnites are extremely rare in Greenland. Birkelund (1956) described ten specimens, about half of which were fragments, in her monograph of the belemnites from the Nûgssuaq and Svartenhuk peninsulas in West Greenland (Fig. 1). She referred the specimens to Actinocamax groenlandicus Birkelund, 1956, A. aff. groenlandicus, $A$. cf. primus Arkhangelsky, 1912, A. sp., and Groenlandibelus rosenkrantzi (Birkelund, 1956).

Donovan (1954) recorded a number of poorly preserved belemnite fragments from Geographical Society $\varnothing$ in northern East Greenland, which according to J. A. Jeletzky (in Donovan 1954) might be assigned to Actinocamax verus? Miller, 1823, and Belemnitella? sp. indet., implying a Santonian or Early Campanian age of the rocks yielding the belemnites.

Swinnerton (1943) described four incomplete belemnite specimens from the Kangerdlugssuaq area of southern East Greenland (Fig. 2). He used open nomenclature and referred the specimens to $A$. cf. blackmorei Crick, 1907, A. cf. plenus (Blainville, 1825), and $A$. sp. Swinnerton suggested on the basis of $A$. cf. blackmorei that

This paper is a contribution to IGCP-Project No. 58, Mid-Cretaceous Events.

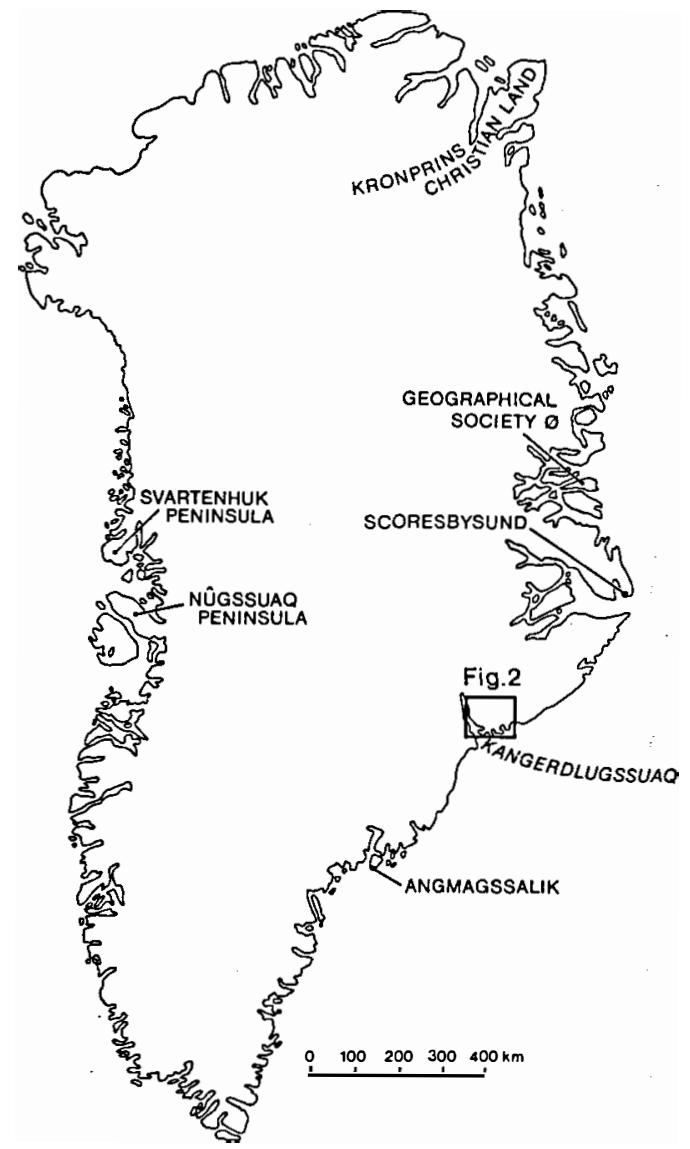

Fig. 1. Map of Greenland showing areas from which Upper Cretaceous belemnites have been recorded. 
the sediments yielding the belemnites were from the 'Senonian', and later workers (i.a. Donovan 1957; Birkelund \& Perch-Nielsen 1976; Soper, Higgins, Downie, Matthews \& Brown 1976; Higgins \& Soper 1981; Nielsen, Soper, Brooks, Faller, Higgins \& Matthews 1981; and Brooks \& Nielsen 1982) have followed this point of view.

For the sake of completeness it should be added that Upper Cretaceous belemnites were recorded from Kronprins Christian Land in eastern North Greenland by Håkansson, Heinberg \& Stemmerik (1981). However, generic and specific determinations were not given.

During field-work in 1982 in the Kangerdiugssuaq area an external mould of a belemnite was found by the junior author. This belemnite is closely comparable to representatives of Actino- camax known from the lover Upper Cretaceous of West Greenland and North America. On the basis of this belemnite it is possi ble to revise part of the belemnite material described by Swinnerton, and to improve the biostratigraphic dating of the lithostratigraphic units proposed by Soper et al. (1976), Higgins \& Soper (1981), and Nielsen et al. (1981) for the marine sediments in the Kangerdlugssuaq area in East Greenland.

\section{General geological framework and stratigraphy}

The geology of the Kangerdlugssuaq area was described recently by Soper et al. (1976), Higgins

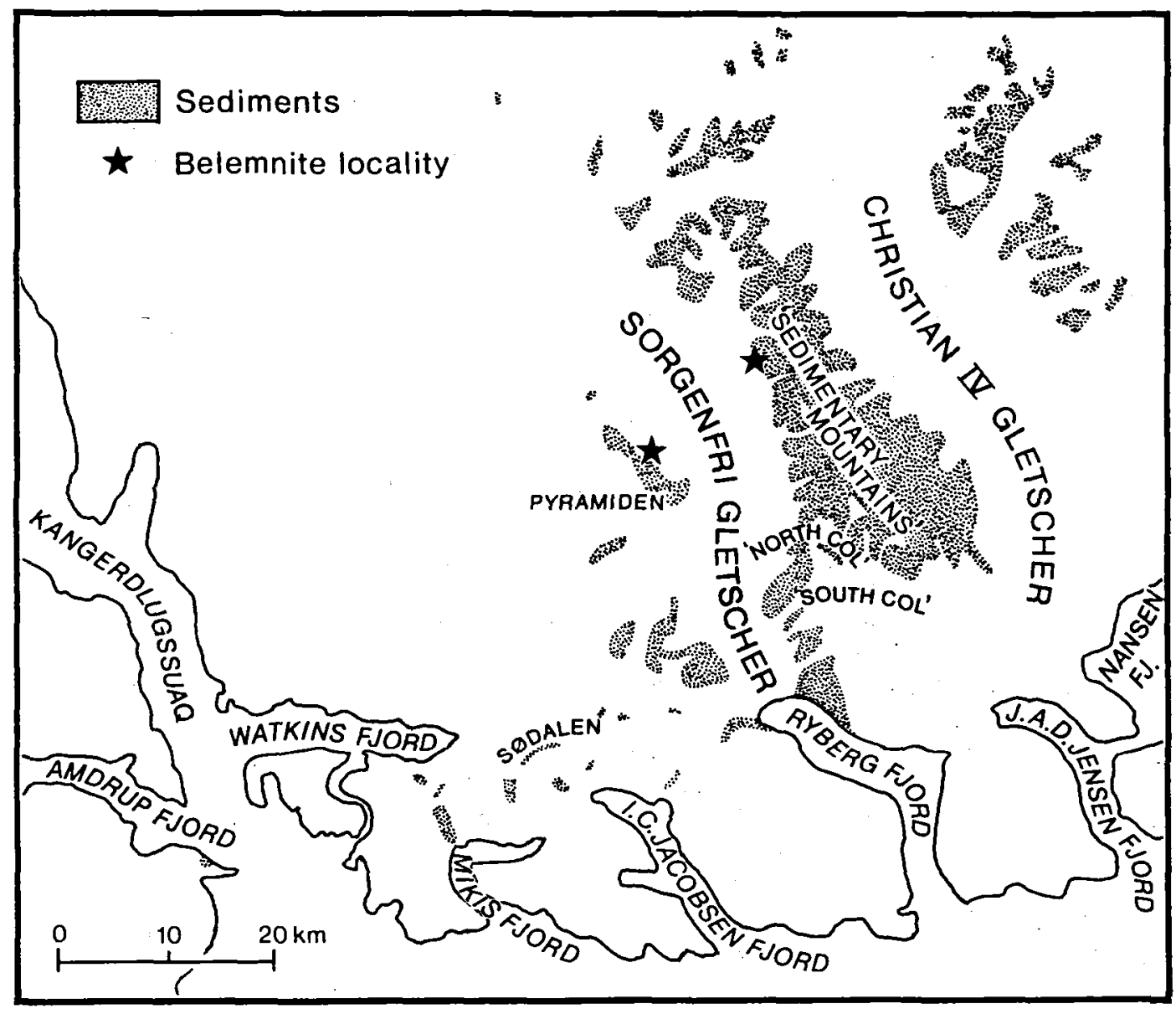

Fig. 2. Map of the Kangerdlugssuaq area, southern East Greenland, showing distribution of sediments and localities mentioned in the text. Place names in inverted commas as yet not authorized. After Higgins \& Soper (1981). 
\& Soper (1981), Nielsen et al. (1981), and Brooks \& Nielsen (1982), and the following review is based on these papers.

The Cretaceous-early Tertiary sedimentary succession constituting the Kangerdlugssuaq Group (Fig. 3) is sandwiched between Precambrian gneisses and Tertiary basalts. It is subdivided into a lower, Sorgenfri Formation and an upper, Ryberg Formation (Soper et al. 1976). The base of the Cretaceous sediments and the contact between the two formations have not been observed.

The Sorgenfri Formation is known only from one outcrop situated at 'South Col' in the 'Sedimentary Mountains' east of Sorgenfri Gletscher. The formation is about $30 \mathrm{~m}$ thick and consists of grey sandy shales with calcareous nodules (Soper et al. 1976). The lower shales have yielded dinoflagellates of Late Albian age, and lower Cenomanian ammonites were recorded from the top of the shales (Soper et al. 1976). According to Soper et al. (1976: 86) the formation probably occurs farther north in the lower part of the Pyramiden sequence described by Wager (1947).
The Ryberg Formation is characterized by coarser sediments that the underlying formation and consists of micaceous shales and thin planar sandstones (Soper et al. 1976). 'Senonian' dinoflagellates were recorded from the head of Ryberg Fjord, Campanian dinoflagellates from Sødalen, and upper Campanian or lower Maastrichtian ammonites from 'South Col' (Higgins \& Soper 1981). According to Soper et al. (1976) the ammonites came from 'North Col'. Soper et al. (1976) stated that the oldest dated unit of the Ryberg Formation is from Pyramiden. In this context they cited the belemnites described by Swinnerton (1943). In describing these belemnites from the lowest beds of the Pyramiden sequence, Swinnerton (1943) suggested that they were of 'Senonian' age (see below). Consequently, the lower part of the Ryberg Formation was thought to be of Santonian or Early Campanian age by Soper et al. (1976). However, the determination of Swinnerton is not considered reliable (see below). The belemnites are most likely of Middle Turonian age, with a maximum possible stratigraphic range from uppermost Lower-Upper Turonian. If the belem-

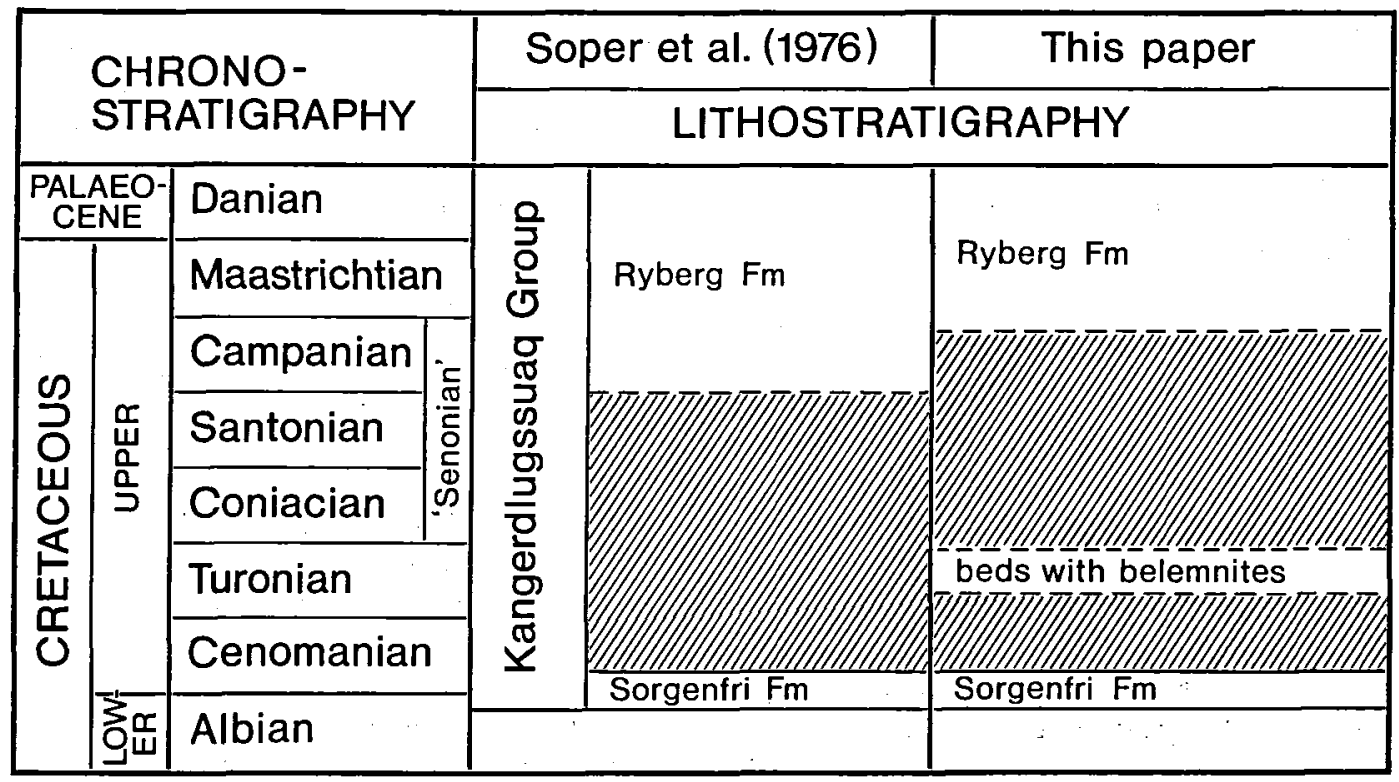

Fig. 3. Stratigraphic scheme of the Cretaceous-Early Tertiary Kangerdlugssuaq Group in southern East Greenland. The beds with belemnites, an informal lithostratigraphic unit, are most likely of Middle Turonian age, but it cannot be ruled out that the maximum possible stratigraphic range is from uppermost Lower-Upper Turonian. 'Senonian' is not used by Cretaceous workers today, because it is an omnibus term conventionally embracing the Coniacian, Santonian, and Campanian Stages. However, some authors have also included the Maastrichtian Stage in the 'Senonian'. 
nites are derived from the lower part of the Ryberg Formation, this formation can now be dated as being of Turonian-Danian age.

It should, however, be noted that Soper et al. (1976) suggested that the Sorgenfri Formation might also occur in the lower part of the Pyramiden sequence (see above). If this suggestion is correct and the belemnites were collected from this formation, then the Sorgenfri Formation ranges in age from Late Albian-Turonian.

Instead of extending the range of one or other of the described formations, it is also possible to consider the beds yielding the belemnites as an informal lithostratigraphic unit most likely of Middle Turonian age, placed between the Sorgenfri and Ryberg Formations. This suggestion is favoured by the present authors (Fig. 3) until more data have been gathered about the biostratigraphy of the Cretaceous of the Kangerdlugssuaq area.

\section{Description of the belemnite locality}

The concretion with the external mould of the belemnite guard was collected loose among erosional debris on the west flank of the 'Sedimentary Mountains' about $1200 \mathrm{~m}$ above sea-level (Fig. 2).

The sedimentary sequence of the 'Sedimentary Mountains' is commonly interrupted by dykes and sills, which are more resistant to erosion than the sediments. The dykes, therefore, stretch like walls across the landscape, and sills form roofs above the sediments.

The Cretaceous marine sediments in this area, apart from on vertical or quasi-vertical slopes, are densely covered by fragments of harder rocks, mainly volcanic intrusives and baked sediments. It seems likely that the concretion with the belemnite mould is derived from black, micaceous, silty shales similar to those that could be seen in fairly deep melt-water scar about $100 \mathrm{~m}$ above the site where the concretion was found. A few kilometres further to the south, within the same general level, a grey, micaceous silt-stone was exposed, which yielded fragments of an inoceramid bivalve mollusc, an impression of an ammonite, and a Rhizocorallium-like trace fossil.

The lowest marine sediments were found along a small tributary glacier to the Sorgenfri
Gletscher, north of the belemnite locality, about $1070 \mathrm{~m}$ above sea-level. At this place black shales with concretionary bands and nodules formed a steep wall 7-10 m high. No macrofossils were found here. The base of the Cretaceous sediments was not observed.

\section{Systematic description}

Christensen (1982) discussed at length the species concept of Upper Cretaceous belemnites, the taxonomic value of various morphological characters, and the classification proposed by Naidin (1964). This discussion was concerned with Upper Cretaceous belemnites belonging to Belemnitellidae Pavlov, 1914, and a short review is given below.

The classification of Naidin (1964) was not followed by Christensen (1982), because it was considered unsatisfactory from a phylogenetic point of view and the subgenera proposed by Naidin were considered superfluous. Granulation of belemnites was formerly given great taxonomic significance (e.g. Stolley 1916; Jeletzky 1950, 1961). Christensen (1982), after an analysis of granulation within the genera Gonioteuthis Bayle and Belemnellocamax Naidin, demonstrated that too much importance had been attributed to the taxonomic value of granulation, and that this character may not always be diagnostic at the species level; this point of view was already stressed by Birkelund (1956: 11) and Naidin (1964: 142-143). In contrast to Jeletzky (1950, 1961), Christensen (1982) considered the shape of the guard to be a more significant character that the presence of granulation.

Family Belemnitellidae Pavlov, 1914

Genus Actinocamax Miller, 1823

Actinocamax cf. manitobensis (Whiteaves, 1889) Fig. 4A

Preservation. - The belemnite was found as an external mould in a concretion. The mould shows the ventral surface and parts of the lateral surface. A cast reveals that the concretion was slightly compressed causing a slight deformation of the mould. 
Description. - The guard is large and slender, and slightly lanceolate in ventral view. The length of the guard is ca. $97,5 \mathrm{~mm}$, and the maximum lateral diameter, situated in the middle part of the guard, is ca. $12,8 \mathrm{~mm}$. Anteriorly, the lateral diameter is estimated to be $10,0 \mathrm{~mm}$. The anterior end of the guard is flat with a pit in its centre, and the cross-section seems to be pointed oval. The anterior end shows the concentric growth layers of the guard, radial ridges, and a slightly projecting ridge round the margin. Ventrally, the anterior end has a deeply incised fissure, broadly gaping in its outer part. The fissure reaches almost to the centre of the flat anterior end and is about $8 \mathrm{~mm}$ long. It continues posteriorly in a shallow furrow for about $10 \mathrm{~mm}$, and then disappears. Presumably, the gabing ventral fissure and shallow furrow were enlarged by weathering.

The guard has granules on parts of the ventral and lateral surfaces. The granules are scattered and do not form any specific pattern. The granulation may originally have been more extensive. No other surface markings have been observed.

\section{Swinnerton's belemnites from East Greenland}

The belemnites described by Swinnerton (1943) from East Greenland were collected by L. R. Wager in 1935-1936 from marine sediments exposed on the ridge south-east of Sortekap (= Pyramiden of Soper et al. 1976) in the Kangerdlugssuaq area. The sediments form the lowest beds in a sequence of shales and sandstones which most likely rest upon Precambrian basement gneisses. The belemnite material consisted of fragments of four specimens and came from a dark, slightly sandy and micaceous shale.

Swinnerton (1943) compared for obvious reasons the specimens with European species, because Upper Cretaceous belemnites from Greenland and North America were virtually unknown at that time. He used open nomenclature and assigned two of the specimens to $A$. cf. blackmorei, one specimen to $A$. cf. plenus, and one specimen to $A$. sp. According to Swinnerton, A. blackmorei occurs rarely in the English Upper Chalk at the base of the Gonioteuthis quadrata Zone, and he suggested therefore, that the sediments yielding the specimens of $A$. cf. blackmorei were of 'Senonian' age. The specimens from the Kangerdlugssuaq area have been commented upon by various authors (e.g. Jeletzky 1950; Birkelund 1956), but a necessary revision of the material has not been performed. C. J. Wood (Institute of Geological Sciences, London) has searched for the belemnites in 1975 but has not
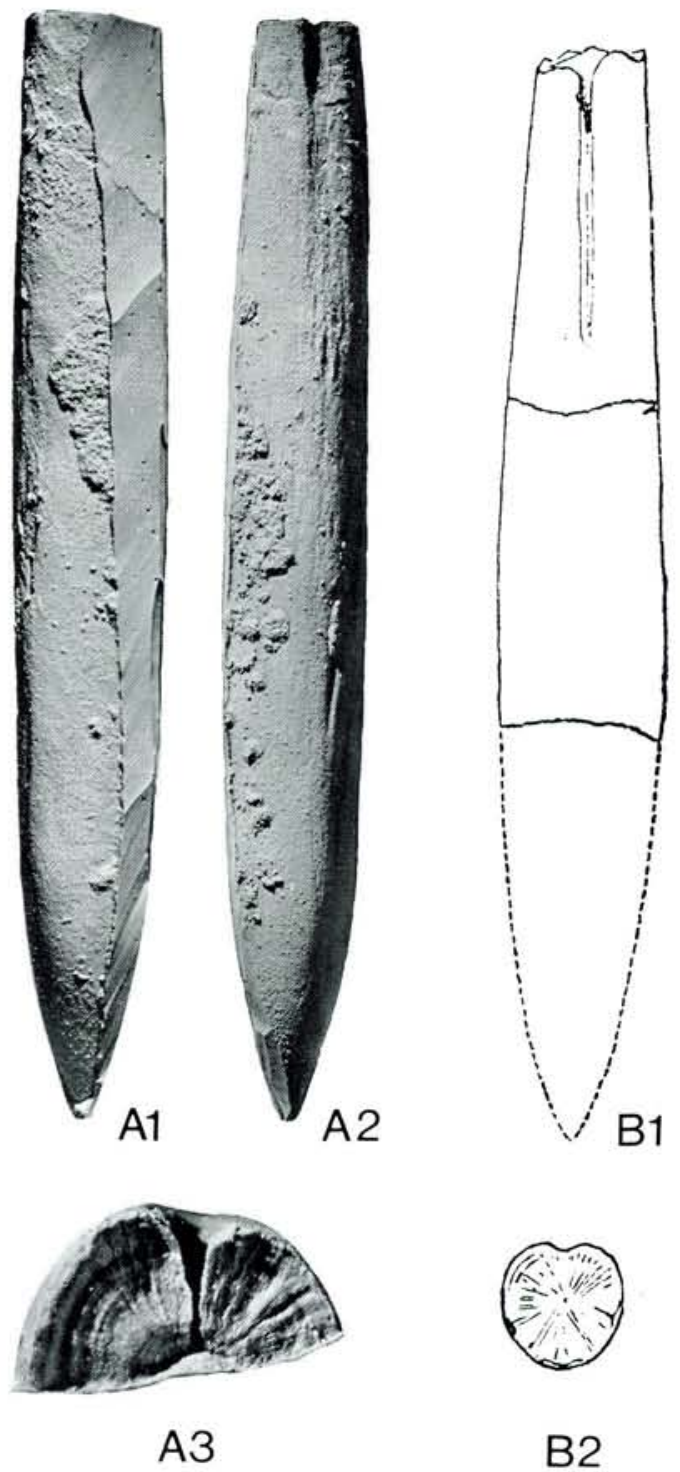

B2

Fig. 4. A: Actinocamax cf. manitobensis (Whiteaves, 1889) from the 'Sedimentary Mountains' east of the Sorgenfri Gletscher. Silicone rubber cast of external mould. MGUH 16111. 1: Lateral view. -2 : Ventral view. -3 : View of the anterior end, X 3. B: Actinocamax cf. manitobensis (Whiteaves, 1889) from Pyramiden. 1: Ventral view, -2 : View of the anterior end. Reproduced from Swinnerton (1943, Fig. 1), who figured the specimen as Actinocamax cf. blackmorei Crick, 1907. 
succeeded in locating them. The specimens are apparently neither in the British Museum (Nat.Hist.) in London, nor in the geological institutes or museums in Reading, Oxford, Newcastle, and Nottingham (C. J. Wood, in litt. January 1976).

A. blackmorei is very rare. It was established on the basis of only one incomplete specimen, in which the most anterior part of the guard is missing, One of us (WKC) has studied the holotype in the British Museum (Nat.Hist.) in London, and the species was placed in Belemnellocamax ex gr. grossouvrei (Janet 1891) by Christensen (1975). The $B$. grossouvrei group needs revision, since eight species and subspecies based on eleven specimens have been erected in western Europe. Members of the $B$. grossouvrei group are characterized by large, ventrally flattened guards and a shallow pseudoalveolus, the cross-section of which is subtriangular; the $B$. grossouvrei group is known from Lower Santonian-Lower Campanian (Christensen, unpublished information).

The specimen referred to as $A$. cf. blackmore by Swinnerton (1943, Fig. 1) (reproduced here as Fig. 4B) differs notably from the $B$. grossouvrei group in terms of the structure of the alveolar end. In contrast, the specimen is very similar to that of $A$. cf. manitobensis described above. Both specimens are large, slender and lanceolate in ventral view with the maximum diameter placed in the middle part of the guard. Moreover, both specimens have a flat anterior end with a projecting ridge round the margin, and a deeply incised ventral fissure which continues posteriorly in a shallow furrow. The specimen of Swinnerton differs only from $A$. cf. manitobensis in being slightly more stout and lanceolate in ventral view and by having a low conical elevation in the centre of the flat anterior end. In addition, Swinnerton's specimen is not granulated.

The slight differences in the shape of the guard and structure of the anterior end are not considered to be of taxonomic importance in view of the known variability of these characters in other belemnites species. The two specimens are regarded as conspecific, even though one of the specimens is granulated.

A specific determination of the three other belemnite fragments figured by Swinnerton is not possible at present.
Affinity of $A$. cf. manitobensis from southern East Greenland

The two specimens referred to as $A$. cf. manitobensis from southern East Greenland are very closely comparable to representatives of $A c$ tinocamax from the North American palaeobiogeographic Province sensu Christensen (1975, 1976), particularly $A$. aff. groenlandicus from West Greenland, and A. manitobensis, A. sternbergi Jeletzky, 1961, and $A$. walkeri Jeletzky, 1961 from North America.

A. manitobensis was revised by Jeletzky (1950, 1961) on the basis of a small number of specimens the stratigraphic control of which was poor. The specimens of $A$. manitobensis from Manitoba in Canada described by Jeletzky (1950) were supposed to be derived from the Assiniboine Member of the Favel Formation (Fig. 5). Moreover, A. manitobensis was also recorded from Canada from the Assiniboine Member of Saskatchewan, the Cardium Formation of Alberta, and the Tuskoola Sandstones of British Columbia (Jeletzky 1961: 515).

McNeil \& Caldwell (1981) correlated the Assiniboine Member with the Fairport Chalky Shale Member of the Western Interior of USA (Fig. 5). The Fairport Member is of Middle Turonian age (Kauffman 1977). According to Stott (1967) the Tuskoola Sandstones occur in the upper part of the Vimy Member of the Kaskapau Formation, and the Vimy Member was correlated with the Keld Member of the Favel Formation of Manitoba. The Keld Member is of Early Turonian age (McNeil \& Candwell 1981). According to Stoot (1967) the age of the Cardium Formation is determined by its stratigraphic position between dated beds rather that by its indigneous fossils. Stott (1963: 136) tentatively correlated the main part of the Cardium Formation with the upper part of the Carlile Shale Formation.

The stratigraphic control of the specimens of A. manitobensis from Kansas described by Jeletzky (1961) was extremely poor. One specimen ( $A$. manitobensis f. typ.) was said to come from the Niobrara Formation, but according to Jeletzky (1961: 509-510) the specimen probably was mislabelled and he tentatively suggested that it came from the Fairport Member. Another specimen ( $A$. manitobensis var. kansanus Je- 
Description. - The guard is large and slender, and slightly lanceolate in ventral view. The length of the guard is ca. $97,5 \mathrm{~mm}$, and the maximum lateral diameter, situated in the middle part of the guard, is ca. $12,8 \mathrm{~mm}$. Anteriorly, the lateral diameter is estimated to be $10,0 \mathrm{~mm}$. The anterior end of the guard is flat with a pit in its centre, and the cross-section seems to be pointed oval. The anterior end shows the concentric growth layers of the guard, radial ridges, and a slightly projecting ridge round the margin. Ventrally, the anterior end has a deeply incised fissure, broadly gaping in its outer part. The fissure reaches almost to the centre of the flat anterior end and is about $8 \mathrm{~mm}$ long. It continues posteriorly in a shallow furrow for about $10 \mathrm{~mm}$, and then disappears. Presumably, the gabing ventral fissure and shallow furrow were enlarged by weathering.

The guard has granules on parts of the ventral and lateral surfaces. The granules are scattered and do not form any specific pattern. The granulation may originally have been more extensive. No other surface markings have been observed.

\section{Swinnerton's belemnites from East Greenland}

The belemnites described by Swinnerton (1943) from East Greenland were collected by L. R. Wager in 1935-1936 from marine sediments exposed on the ridge south-east of Sortekap (= Pyramiden of Soper et al. 1976) in the Kangerdlugssuaq area. The sediments form the lowest beds in a sequence of shales and sandstones which most likely rest upon Precambrian basement gneisses. The belemnite material consisted of fragments of four specimens and came from a dark, slightly sandy and micaceous shale.

Swinnerton (1943) compared for obvious reasons the specimens with European species, because Upper Cretaceous belemnites from Greenland and North America were virtually unknown at that time. He used open nomenclature and assigned two of the specimens to $A$. cf. blackmorei, one specimen to $A$. cf. plenus, and one specimen to $A$. sp. According to Swinnerton, A. blackmorei occurs rarely in the English Upper Chalk at the base of the Gonioteuthis quadrata Zone, and he suggested therefore, that the sediments yielding the specimens of $A$. cf. blackmorei were of 'Senonian' age. The specimens from the Kangerdlugssuaq area have been commented upon by various authors (e.g. Jeletzky 1950; Birkelund 1956), but a necessary revision of the material has not been performed. C. J. Wood (Institute of Geological Sciences, London) has searched for the belemnites in 1975 but has not
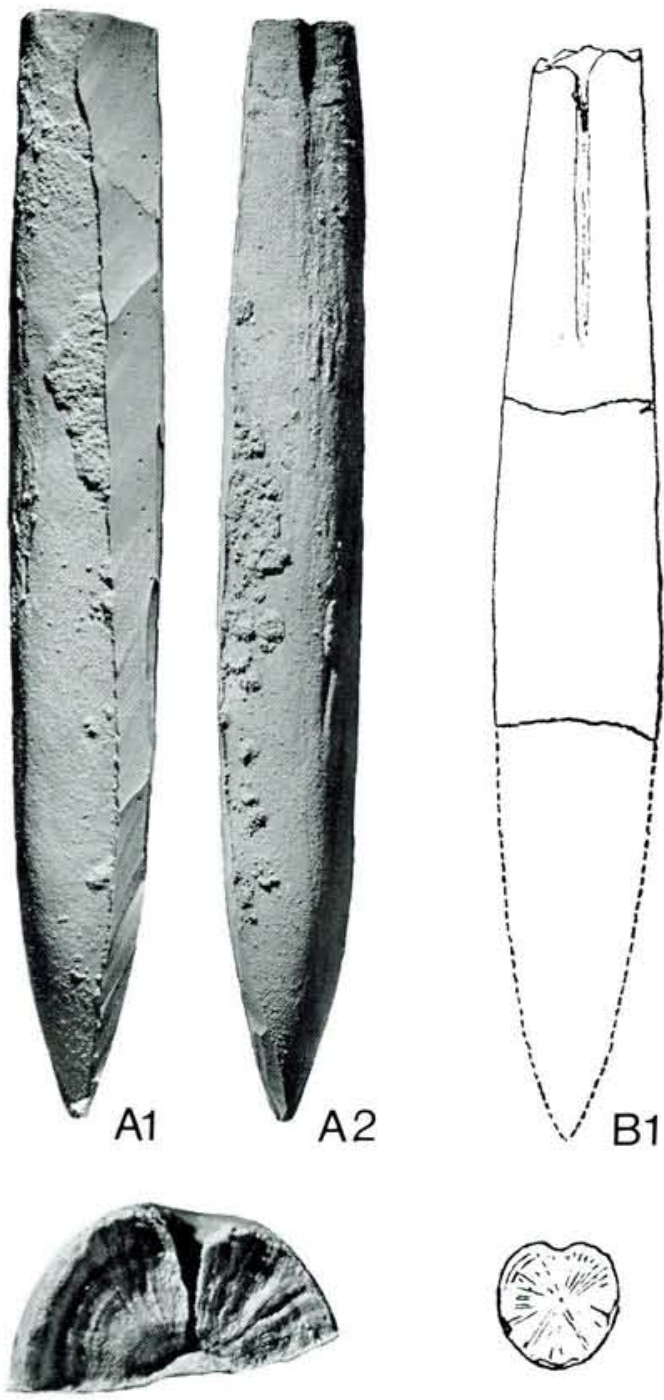

A3

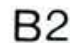

Fig. 4. A: Actinocamax cf. manitobensis (Whiteaves, 1889 from the 'Sedimentary Mountains' east of the Sorgenfri Gletscher. Silicone rubber cast of external mould. MGUH 16111. 1: Lateral view. - 2: Ventral view. - 3: View of the anterior end, X 3. B: Actinocamax cf. manitobensis (Whiteaves, 1889) from Pyramiden. 1: Ventral view. -2 : View of the anterior end. Reproduced from Swinnerton (1943, Fig. 1), who figured the specimen as Actinocamax cf. blackmorei Crick, 1907. 
succeeded in locating them. The specimens are apparently neither in the British Museum (Nat.Hist.) in London, nor in the geological institutes or museums in Reading, Oxford, Newcastle, and Nottingham (C. J. Wood, in litt. January 1976).

A. blackmorei is very rare. It was established on the basis of only one incomplete specimen, in which the most anterior part of the guard is missing, One of us (WKC) has studied the holotype in the British Museum (Nat.Hist.) in London, and the species was placed in Belemnellocamax ex gr. grossouvrei (Janet 1891) by Christensen (1975). The $B$. grossouvrei group needs revision, since eight species and subspecies based on eleven specimens have been erected in western Europe. Members of the $B$. grossouvrei group are characterized by large, ventrally flattened guards and a shallow pseudoalveolus, the cross-section of which is subtriangular; the $B$. grossouvrei group is known from Lower Santonian-Lower Campanian (Christensen, unpublished information).

The specimen referred to as $A$. cf. blackmore $i$ by Swinnerton (1943, Fig. 1) (reproduced here as Fig. 4B) differs notably from the $B$. grossouvrei group in terms of the structure of the alveolar end. In contrast, the specimen is very similar to that of $A$. cf. manitobensis described above. Both specimens are large, slender and lanceolate in ventral view with the maximum diameter placed in the middle part of the guard. Moreover, both specimens have a flat anterior end with a projecting ridge round the margin, and a deeply incised ventral fissure which continues posteriorly in a shallow furrow. The specimen of Swinnerton differs only from $A$. cf. manitobensis in being slightly more stout and lanceolate in ventral view and by having a low conical elevation in the centre of the flat anterior end. In addition, Swinnerton's specimen is not granulated.

The slight differences in the shape of the guard and structure of the anterior end are not considered to be of taxonomic importance in view of the known variability of these characters in other belemnites species. The two specimens are regarded as conspecific, even though one of the specimens is granulated.

A specific determination of the three other belemnite fragments figured by Swinnerton is not possible at present.
Affinity of $A$. cf. manitobensis from southern East Greenland

The two specimens referred to as $A$. cf. manitobensis from southern East Greenland are very closely comparable to representatives of $A C$ tinocamax from the North American palaeobiogeographic Province sensu Christensen (1975, 1976), particularly $A$. aff. groenlandicus from West Greenland, and A. manitobensis, A. sternbergi Jeletzky, 1961, and $A$. walkeri Jeletzky, 1961 from North America.

A. manitobensis was revised by Jeletzky (1950, 1961) on the basis of a small number of specimens the stratigraphic control of which was poor. The specimens of $A$. manitobensis from Manitoba in Canada described by Jeletzky (1950) were supposed to be derived from the Assiniboine Member of the Favel Formation (Fig. 5). Moreover, A. manitobensis was also recorded from Canada from the Assiniboine Member of Saskatchewan, the Cardium Formation of Alberta, and the Tuskoola Sandstones of British Columbia (Jeletzky 1961: 515).

McNeil \& Caldwell (1981) correlated the Assiniboine Member with the Fairport Chalky Shale Member of the Western Interior of USA (Fig. 5). The Fairport Member is of Middle Turonian age (Kauffman 1977). According to Stott (1967) the Tuskoola Sandstones occur in the upper part of the Vimy Member of the Kaskapau Formation, and the Vimy Member was correlated with the Keld Member of the Favel Formation of Manitoba. The Keld Member is of Early Turonian age (McNeil \& Candwell 1981). According to Stoot (1967) the age of the Cardium Formation is determined by its stratigraphic position between dated beds rather that by its indigneous fossils. Stott (1963: 136) tentatively correlated the main part of the Cardium Formation with the upper part of the Carlile Shale Formation.

The stratigraphic control of the specimens of A. manitobensis from Kansas described by Jeletzky (1961) was extremely poor. One specimen (A. manitobensis f. typ.) was said to come from the Niobrara Formation, but according to Jeletzky (1961: 509-510) the specimen probably was mislabelled and he tentatively suggested that it came from the Fairport Member. Another specimen (A. manitobensis var. kansanus Je- 


\begin{tabular}{|c|c|c|c|c|c|c|c|}
\hline & & \multicolumn{2}{|c|}{$\begin{array}{l}\text { Western Interior, USA } \\
\text { central part } \\
\text { (Kauffman 1977) }\end{array}$} & \multicolumn{2}{|c|}{$\begin{array}{l}\text { Western Interior, Canada } \\
\text { eastern part } \\
\text { (McNeil \& Caldwell 1981) }\end{array}$} & \multicolumn{2}{|c|}{$\begin{array}{l}\text { Western Interior, Canada } \\
\text { western part } \\
\text { (Stott 1963,1967, 1975) }\end{array}$} \\
\hline \multicolumn{2}{|c|}{$\begin{array}{l}\text { Chrono- } \\
\text { stratio- } \\
\text { graphy } \\
\end{array}$} & \multicolumn{2}{|c|}{ Lithostratigraphy } & & ithostratigraphy & \multicolumn{2}{|r|}{ Lithostratigraphy } \\
\hline 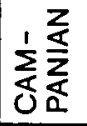 & - & 递㐫 & & \multirow{9}{*}{\multicolumn{2}{|c|}{. }} & \multirow{5}{*}{\multicolumn{2}{|c|}{$\checkmark$}} \\
\hline$\underset{s}{z}$ & 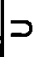 & \multirow{4}{*}{$\begin{array}{l}E \\
\frac{E}{\square} \\
\frac{\pi}{\sigma} \\
\frac{0}{0} \\
\frac{0}{z}\end{array}$} & \multirow{3}{*}{ Smoky Hill Mb } & & & & \\
\hline 点 & - & & & & & & \\
\hline \multirow{2}{*}{$\begin{array}{l}z \\
\mathbf{z} \\
0 \\
\mathbf{z} \\
\mathbf{z} \\
0\end{array}$} & $\supset$ & & & & & & \\
\hline & 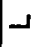 & & Fort Hays Limestone Mb & & & & \\
\hline \multirow{6}{*}{ 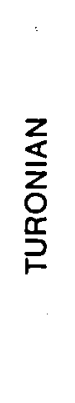 } & \multirow{2}{*}{ כ } & \multirow{5}{*}{ 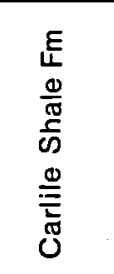 } & Upper Shale Mb & & & \multirow{4}{*}{ 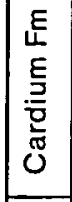 } & \\
\hline & & & Juana Lopez Mb & & & & \\
\hline & \multirow{3}{*}{$\Sigma$} & & Codell Sandstone $\mathrm{Mb}$ & & & & \\
\hline & & & Blue Hill Shale Mb & & & & \\
\hline & & & $\begin{array}{l}\text { Fairport Chalky } \\
\text { Shale Mb }\end{array}$ & \multirow{2}{*}{$\begin{array}{l}\frac{E}{4} \\
\bar{\Phi} \\
\stackrel{\varpi}{\mathbb{1}}\end{array}$} & Assiniboine $\mathrm{Mb}$ & \multirow{2}{*}{ 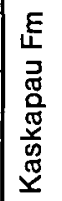 } & \multirow{2}{*}{ Vimy Mb } \\
\hline & 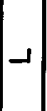 & 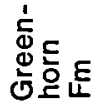 & $\begin{array}{l}\text { Bridge Creek } \\
\text { Limestone Mb }\end{array}$ & & Keld Mb & & \\
\hline
\end{tabular}

Fig. 5. Stratigraphic scheme of the Turonian-Lower Campanian of the Western Interior of North America.

letzky, 1961) probably came from the Fairport Member. The third specimen ( $A$. manitobensis var. spicularis Jeletzky, 1961) was found in a miscellaneous collection of fossils donated to the Museum of the Fort Hays Kansas State College by a private collector, and the stratigraphic horizon was unknown.

Hattin (1962) recorded a single specimen of $A$. manitobensis from the middle part of the Fairport Member in addition to Collignoniceras woolgari and various inoceramid species. Hattin (1962) suggested that the three specimens of $A$. manitobensis from Kansas described by Jeletzky (1961) probably also came from the Fairport Member.

In summary, it can be concluded that $A$. manitobensis is recorded with certainty only from the Middle Turonian Collignoniceras woolgari Zone (middle part of the Fairport Member). However, it cannot be ruled out that the maximum possible stratigraphic range of the species is from uppermost Lower-Upper Turonian.

According to Jeletzky (1961) A. manitobensis is characterized by having a large, stout to slender guard, which is subcylindrical to fairly lanceolate in ventral view, and subcylindrical, fairly lanceolate, or high conical in lateral view. The alveolar end may be developed as a low cone-shaped alveolar fracture or have a more or less shallow pseudoalveolus. The species is not granulated. The amended diagnosis of $A$. manitobensis proposed by Jeletzky (1961: 507) was critized by Christensen (1982), because it is too comprehensive to be workable. Many species of $A c$ tinocamax could be classified as $A$. manitobensis, and Christensen (1982) therefore concluded that A. manitobensis needed revision based on stratigraphically well-documented material.

A. sternbergi was established on the basis of a 
single specimen (Jeletzky 1961, Pl. 72: 5) which probably came from the Niobrara Formation of Kansas (Fig. 5). Jeletzky (1961) accepted the supposed derivation of the specimen and suggested that the species might be of late Coniacian-early Santonian age. However, on the basis of white chalky matrix present on the alveolar end of the guard (Jeletzky 1961: 520) it can be suggested that the specimen came from the Fairport Member, as did the specimen of $A$. manitobensis $\mathrm{f}$. typ. mentioned above. $A$. sternbergi is characterized by being relatively large, slender, and slightly lanceolate in ventral niew. The anterior end is flat with a low cone-shaped elevation in its centre. Ventrally, the anterior end exhibits a fissure, gaping in its outer part, and the length of the fissure is $8 \mathrm{~mm}$. In addition, the entire surface of the guard is covered by closely spaced small granules which do not form any definite arrangement.

A. sternbergi was distinguished by Jeletzky (1961: 519) from all other species of $A c$ tinocamax from North America only by being granulated. It has been shown elsewhere (Christensen 1982; see also discussion abové) that granulation may not always be diagnostic at the species level, and $A$. sternbergi is in fact very similar to $A$. manitobensis in many morphological characters; compare for example the holotype of $A$. sternbergi with $A$. manitobensis f. typ. from Kansas (figured by Jeletzky 1961, Pl. 72: 2 and Pl. 72: 5) Therefore, it is uncertain if $A$. sternbergi should be retained as a valid species or be placed in synonymy.

The only known specimen of $A$. aff. groenlandicus (Birkelund 1956, Pl. 1: 4) was found in a conglomerate together with fossils of Late Campanian age; the guard was probably reworked from older Late Cretaceous sediments (Birkelund 1956: 11-12). A. aff. groenlandicus is characterized by being slender and slightly lanceolate in ventral view. The anterior end has a very low cone-shaped alveolar fracture, and there is a projecting ridge around the margin. Ventrally the anterior end shows a fissure, about $3 \mathrm{~mm}$ long, which is gaping in its outer part. The guard carries small, low granules on the middle part of the ventral surface, and the granules do not form any pattern. The granulation may originally have been more extensive. According to Jeletzky
(1961: 519) $A$. aff. groenlandicus and $A$. sternbergi may be conspecific.

The two specimens of $A$. walkeri (Jeletzky 1961, Pl. 72: 3-4) probably came from the Niobrara Formation of Kansas. Jeletzky (1961: 526) accepted this derivation and suggested that A. walkeri came from beds of Coniacian age. However, on the basis of the adherent matrix the two specimens might equally well have come from the Fairport Member. A. walkeri is distinguished by being medium-sized, stout, and weakly lanceolate to subcylindrical in ventral view. The surface of the guard is virtually smooth. The alveolar end is flat and has ventrally a short furrow. According to Jeletzky (1961: 525) $A$. walkeri is closely allied to $A$. manitobensis. It differs from this species notably by being shorter and sturdier, and having a virtually smooth guard.

From the previous discussion it is evident that the genus Actinocamax from North America needs revision, based on new material from well-known stratigraphic levels. In spite of this, the two belemnite specimens from southern East Greenland are compared to representatives of Actinocamax from the North American palaeobiogeographic Province, because of their obvious similarity. The two specimens of Actinocamax from southern East Greenland, one of which is granulated, have the same size of the guard as $A$. manitobensis. They are very similar to some specimens of $A$. manitobensis figured by Jeletzky $(1950,1961)$ with respect to shape of the guard and structure of the anterior end. A. manitobensis, however, is not granulated. On the other hand, the two specimens are also rather similar to $A$. sternbergi and $A$. aff. groenlandicus with regard to shape of the guard and structure of the anterior end. The two specimens differ by being larger, and only one specimen from Greenland is granulated. In view of the considerations above, the two specimens of Actinocamax from southern East Greenland are referred to as $A$. cf. manitobensis.

Stratigraphy. - The two specimens of $A$. cf. manitobensis from southern East Greenland were not collected together with other fossils of biostratigraphic value. Therefore, conclusions about the biostratigraphic age of the specimens and the sediments in which they were found can only be 
arrived at indirectly. In North America, $A$. manitobensis is recorded with certainty only from the Middle Turonian, but the stratigraphic range may be from uppermost Lower-Upper Turonian. A. sternbergi was supposed to have been collected from the Niobrara Formation, but the only known specimen might have been mislabelled, as is the case with the specimen of $A$. manitobensis $\mathrm{f}$. typ. from Kansas (see above). The specimen of $A$. sternbergi may have come from the Fairport Member of Middle Turonian age. It is concluded, therefore, that $A$. cf. manitobensis from southern East Greenland is most likely from the Middle Turonian, but that it may indicate a total stratigraphic range from uppermost Lower-Upper Turonian.

\section{Palaeobiogeography}

The North Temperate Realm, characterized by Belemnitellidae, was subdivided into North European and North American Provinces (Christensen 1975, 1976). The latter province includes Greenland and North America, and the belemnites from this province belong to the genera $\mathrm{Ac}$ tinocamax and Belemnitella. Belemnites are not recorded from the Cenomanian of the North America and the first representative are from the Turonian (Jeletzky 1950). In the North European Province the first representative (A. primus) already occurs in the Lower Cenomanian. In the North European Province belemnites have a very restricted distribution in the Turonian and early Coniacian (Christensen 1982).

The belemnites from the North American Province are closely related to those from the North European Province, and Jeletzky (1950, 1971) and Birkelund (1956) suggested that the belemnites migrated from Europe via Greenland and Arctic Cananda to North America, as did certain ammonites (Birkelund 1965). The occurrence of belemnites in southern East Greenland thus provides supporting evidence for this hypothesis.

Acknowledgements. We thank Dr. Finn Surlyk and Prof. Dr. Tove Birkelund, who read the manuscript critically and made valuable comments, and Dr. John Peel, who improved the English of the manuscript. We also thank $\mathrm{C}$. Rasmussen and $\mathrm{S}$. $\mathrm{L}$. Jacobsen for preparation of the drawings and photographs, respectively.

The field-work of EH in East Greenland was supported by the Danish Natural Science Research Council (11-3419).

\section{Dansk sammendrag}

Et nyligt fund af et eksemplar af Actinocamax cf. manitobensis fra Kangerdlugssuaq regionen i Østgronland beskrives, og belemniterne fra samme område, beskrevet af Swinnerton i 1943, diskuteres og revideres. Belemniterne fra Kangerdlugssuaq regionen er nart beslægtede med belemniter béskrevet fra Vestgronland af T. Birkelund i $1956 \mathrm{og}$ fra Nordamerika af J. Jeletzky i 1950 og 1961. Belemniterne fra Kangerdlugssuaq regionen er sandsynligvis fra Mellem Turonien, men den maksimale stratigrafiske udbredelse kan være fra den øverste del af Nedre Turonien til $\emptyset$ vre Turonien. Den biostratigrafiske datering af Sorgenfri og Ryberg Formationerne er let revideret.

\section{References}

Birkelund, T. 1956: Upper Cretaceous belemnites from West Greenland. Meddr Grønl. 137(9), 28 pp.

Birkelund, T. 1965: Ammonites from the Upper Cretaceous of West Greenland. Meddr Gronl. 179(7), 192 pp.

Birkelund, T. and Perch-Nielsen, K. 1976: Late PalaeozoicMesozoic evolution of central East Greenland. In Escher, A. and Watt, W. S. (Eds.): Geology of Greenland, 305-339, Geol. Surv. Greenland, Copenhagen.

Christensen, W. K. 1975: Upper Cretaceous belemnites from the Kristianstad area in Scania. Fossils and Strata 7, $69 \mathrm{pp}$.

Christensen, W. K. 1976: Palaeobiogeography of Late Cretaceous belemnites of Europe. Paläont. Z. 50, 113-129.

Christensen, W. K. 1982: Late Turonian-early Coniacian belemnites from western and central Europe. Bull. geol. Soc. Denm. 31, 63-79.

Donovan, D. T. 1954: Upper Cretaceous fossils from Traill and Geographical Society Øer, East Greenland. Meddr Grønl. $72(6), 33 \mathrm{pp}$.

Donovan, D. T. 1957: The Jurassic and Cretaceous Systems in East Greenland. Meddr Grønl. 155(4), 214 pp.

Hattin, D. E. 1962: Stratigraphy of the Carlile Shale (Upper Cretaceous) in Kansas. Kansas geol. Surv. Bull. 156, 155 pp.

Higgins, A. C. and Soper, N. J. 1981: Cretaceous-Palaeogene subbasaltic and intrabasaltic sediments of the Kangerdlugssuaq area, Central East Greenland. Geol. Mag. 118, 337-353.

Brooks, C. K. and Nielsen, T. F. D. 1982: The Phanerozoic development of the Kangerdlugssuaq area, East Greenland. Meddr Grønl. Geosci. 9, 30 pp.

Håkansson, E., Heinberg, C. and Stemmerik, L. 1981: The Wandel Sea Basin from Holm Land to Lockwood $\varnothing$, eastern Nórth Greenland. Rapp. Gronl. geol. Unders. 106, $47-63$.

Jeletzky, J. A. 1950: Actinocamax from the Upper Cretaceous of Manitoba. Bull. geol. Surv. Can. 15, 27 pp.

Jeletzky, J. A. 1961: Actinocamax from the Upper Cretaceous Benton and Niobrara Formations of Kansas. J. Paleont. $35,501-531$.

Jeletzky, J. A. 1971: Marine Cretaceous biotic provinces of western and Arctic Canada. Proc. North Amer. Paleont. Conv. part 1, 1638-1659.

Kauffman, E. G. 1977: Geological and biological overview: Western Interior Cretaceous Basin. The Mountain Geologist 14, 75-99.

McNeil, D. H. and Caldwell, W. G. E. 1981: Cretaceous rocks and their foraminifera in the Manitoba Escarpment. Geol. Ass. Can. Spec. Pap. 21, 439 pp. 
Naidin, D. P. 1964: The Upper Cretaceous belemnites of the Russian Platform and contiguous regions, Actinocamax, Gonioteuthis, Belemnellocamax. Moscow University Press, 190 pp. [In Russian].

Nielsen, T. F. D., Soper, N. J., Brooks, C. K., Faller, A. M., Higgins, A. C. and Matthews, D. W. 1981: The pre-basaltic sediments and the Lower Basalts at Kangerdlugssuaq, East Greenland: Their stratigraphy, lithology, palaeomagmetism and petrology. Meddr Grønl. Geosci. 6, 25 pp.

Soper, N. J., Higgins, A. C., Downie, C., Matthews, D. W. and Brown, P. E. 1976: Late Cretaceous-early Tertiary stratigraphy of the Kangerdlugssuaq area, East Greenland, and the age of opening of the north-east Atlantic. Jl geol. Soc. Lond. 132, 85-104.

Stolley, E. 1916: Neue Beiträge zur Kenntnis der norddeutschen oberen Kreide, I-IV.Jber. niedersächs. geol. Ver. 9, 95-104.
Stott, D. F. 1963: The Cretaceous Alberta Group and equivalent rocks, Rocky Mountain Foothills, Alberta. Geol. Surv. Can. Mem. 317, 306 pp.

Stott, D. F. 1967: The Cretaceous Smoky Group, Rocky Mountain Foothills, Alberta and British Columbia. Geol. Surv. Can. Bull. 132, 133 pp.

Stott, D. F. 1975: The Cretaceous System in northeastern British Columbia. In: Caldwell, W. G. E. (Ed.): The Cretaceous System in the Western Interior of North America. Geol. Ass. Can. Spec. Pap. 13, 441-467.

Swinnerton, H. H. 1943: Belemnites from East Greenland. Anns Mag. nat. Hist. Ser. 11, 10, 406-410.

Wager, L. R. 1947: Geological investigations in East Greenland. Part IV: The stratigraphy and tectonics of Knud Rasmussens Land and the Kangerdlugssuaq region. Meddr Gronl. 134(5), 64 pp. 